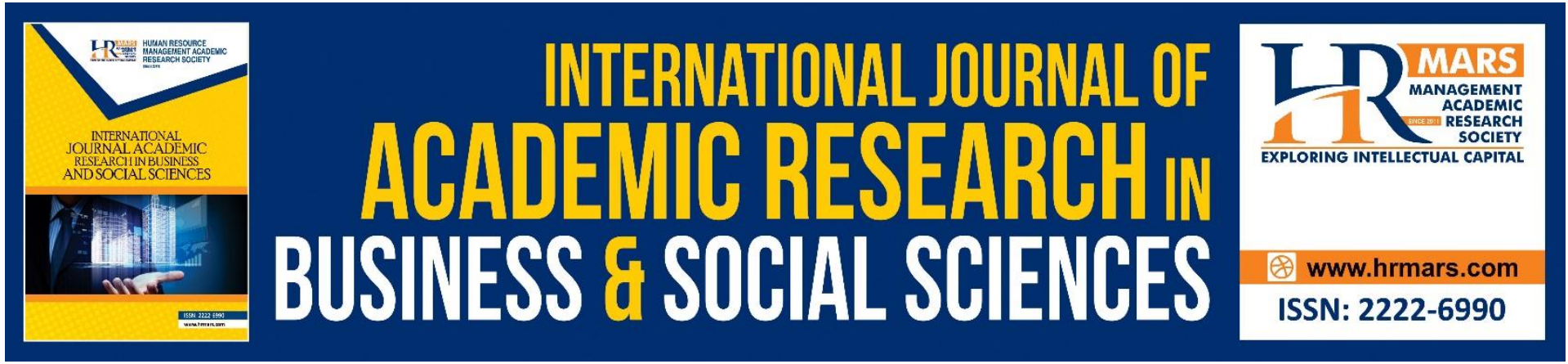

\title{
Technology Acceptance and Technology Usage: Importance to Cash Waqf Contribution
}

Wan Musyirah Binti Wan Ismail, Mohamed Saladin Bin Abdul Rasool, Abd Halim Bin Mohd Noor

To Link this Article: http://dx.doi.org/10.6007/IJARBSS/v11-i9/11082

DOI:10.6007/IJARBSS/v11-i9/11082

Received: 06 July 2021, Revised: 28 July 2021, Accepted: 17 August 2021

Published Online: 10 September 2021

In-Text Citation: (Ismail et al., 2021)

To Cite this Article: Ismail, W. M. B. W., Rasool, M. S. B. A., \& Noor, A. H. B. M. (2021). Technology Acceptance and Technology Usage: Importance to Cash Waqf Contribution. International Journal of Academic Research in Business and Social Sciences, 11(9), 924-953.

Copyright: (c) 2021 The Author(s)

Published by Human Resource Management Academic Research Society (www.hrmars.com)

This article is published under the Creative Commons Attribution (CC BY 4.0) license. Anyone may reproduce, distribute, translate and create derivative works of this article (for both commercial and non-commercial purposes), subject to full attribution to the original publication and authors. The full terms of this license may be seen

at: http://creativecommons.org/licences/by/4.0/legalcode

Vol. 11, No. 9, 2021, Pg. 942 - 953

Full Terms \& Conditions of access and use can be found at http://hrmars.com/index.php/pages/detail/publication-ethics 


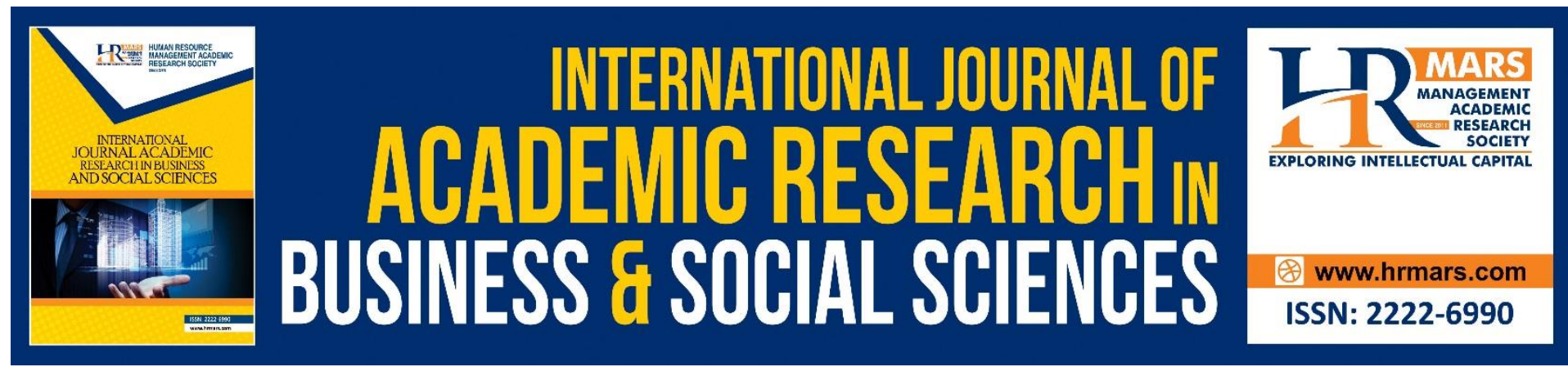

\title{
Technology Acceptance and Technology Usage: Importance to Cash Waqf Contribution
}

\section{Wan Musyirah Binti Wan Ismail'1, Mohamed Saladin Bin Abdul Rasool ${ }^{2}$, Abd Halim Bin Mohd Noor ${ }^{3}$}

${ }^{1}$ Finance and Economy Department, Faculty of Business and Management, Universiti Teknologi Mara, Melaka, Malaysia, ${ }^{2}$ Finance and Economy Department, Faculty of Business and Management, Universiti Teknologi Mara, Melaka, Malaysia, ${ }^{3}$ Finance and Economy Department, Faculty of Business and Management, Universiti Teknologi Mara, Melaka, Malaysia.

Email: musyirah792@uitm.edu.my, saladin@uitm.edu.my,drabdhalim@uitm.edu.my

\begin{abstract}
Cash waqf plays a vital role in the advancement of the socio economic wellbeing of the Muslim community. In Malaysia, cash waqf is one of the alternative instruments that can improve the social welfare and reduce the poverty rate and at the same time, lessen the burden of the government. Scholars believe that contribution of waqf by using cash is much important and more relevant due to its flexibility than waqf properties in the present day. Therefore, collection of cash waqf could be emphasized in order to use its benefit for the betterment of ummah. However, the collection of cash waqf fund in Malaysia is considered relatively low as the total amount collected did not reflect the total amount of Muslim population in Malaysia. Reasons behind this low collection are numerous such as lack of innovative and creative methods to facilitate the collection of cash waqf. Applying variousg technology advancement in cash waqf is envisaged to make the waqf collection more efficient and effective. Therefore, this study aims to investigate the influence of technology acceptance and technology usage towards the intention of cash waf contribution. This cross-section study employed a dataset comprised of 284 respondents working Muslims to investigate the role of technology acceptance and technology usage in influencing them to contribute cash waqf. The Partial Least Squares Structural Equation Modeling (PLS-SEM) was used to analyse data through correlation analysis. Referring to the correlation analysis, the finding discovered that there is a positive and strong relationship between technology usage to the intention of cash waqf contribution, On the other hand, there is negative relationship between technology acceptance and intention to contribute cash waqf.
\end{abstract}

Keywords: Cash Waqf, Technology Advancement, Technology Acceptance, Technology Usage.

\section{Introduction}

Cash Waqf plays an important role in Malaysia as it is categorized in government Sustainable Development Goals (SDG) 16 which promote peaceful and inclusive societies for 
sustainable development, provide access to justice for all and build effective, accountable and inclusive institutions at all levels which would be able to promote peace, justice and develop strong waqf institutions. Many contemporary scholars believe that contribution of cash waqf is more important and relevant due to its flexibility than property waqf (Abdel Mohsin, 2009). The basis of implementation and encouragement of giving cash waqf is due to the thought that cash waqf is something easier for the Muslims to contribute. This is because, with the implementation of cash waqf will help to ensure the ongoing success of the institutions like mosques, libraries, hospitals that were built based on waqf. Previously, many Muslims did not get a chance to participate in waqf because they have no properties to contribute to. This was attributed to their perception that is confined only to properties like land and building that can be endowed because only properties fulfil the condition of waqf; perpetuity, irrevocability and inalienability (Puad et al., 2014; Sabit, 2008).

The aim of the study is to examine the role of technology advancements in aiding the collection of cash waqf from the perspective muslim users. Specifically, the role of technology acceptance and technology usage in influencing the contribution of cash waq would be examined. The present paper is organized as follows. The next section highlights the problem statement followed by the literature review. Hipotesis is explained in section 4 followed by methology in section 5 . Section 6 discusses the findings and followed by conclusion.

\section{Problem Statement}

In Malaysia, the low cash waqf collection level indirectly indicates the awareness about cash waqf is not at a good level. This is parallel to Nasiri et al (2019); Ab Fatah et al (2017) findings that there was still lack of awareness of cash waqf among Muslims. It could be supported by Mat Doa (2020) who emphasized that the collection of cash waqf fund in Malaysia is very low because the total amount collected did not reflect the total amount of Muslim population in Malaysia. Based on report by Yayasan Wakaf Malaysia (YWM) calculation, the average cash waqf per employed Muslim for 2019 was only RM0.28 per employed person. It is strongly agreed by Fuadah Johari who is the Deputy Director Islamic Finance Wealth Management Institution that RM0.28 per employed Muslim is just a small fraction of cash waqf contribution (Johari, 2020).

Jalil et al (2017) agreed that cash waqf collectors should be focused on the types of payment methods that could obtain high priority rates to meet donor's expectation. Therefore, improving cash waqf collection method could be one of the ways to increase the collection of cash waqf. It could be further looking for technology implementation as technology is expected to be one of the best potential factors taht could lead to encourage Muslims to contribute to cash waqf. This is in line with Hasanah \& Pranata, (2019); Fauzi, Yahya, Haron, et al (2019); Adeyemi et al (2016) contention that applying technology advancement in cash waqf makes the waqf collection more efficient and effective. Sargeant \& Woodliffe (2005) concurs that payment methods are the attraction for the donors to retain their contribution. However, there is still limited study covering the payment methods of cash waqf in Malaysia (Jalil et al., 2017).

Technolgy is expected to be the best solution to enhance and improve contribution of cash waqf. It is due to the technology adoption which involves various methods of payment such as mobile banking and mobile payment, show increasing number of usages throughout 2010 (Jalil et al., 2017). Mohsin \& Muneeza (2019), believed that innovation such as Waqfintech could reach a wider audience and benefit more people using innovative financial technology like crowdfunding and blockchain. His point of view was further substantiated by 
Allah Pitchay et al., (2018) that the existing cash waqf models were ineffective in attracting more donors because they were often unsure of how their contributions were utilized. Additionally, mismanagement and lack of transparency in waqf fund management also contributed to the inefficiencies in waqf administration (Mohsin \& Muneeza, 2019; Thaker, 2018; Mohsin et al., 2016). Therefore, innovative finance technology such as crowdfunding platforms and blockchain are expected to improve the management of cash waqf as well as able to increase the collection of cash waqf. Besides that, Hasanah \& Pranata, (2019); Fauzi et al (2019); Adeyemi et al. (2016) proposed that applying technology advancement in cash waqf makes the waqf collection more efficient and effective. In line with this, two variable which are technology acceptance and technology usage used in this research in order to examine the function of technology in increasing contribution of cash waqf.

\section{Literature Review}

Originally, Waqf is involved in contribution of immovable properties such as land and building. Then the contribution of Waqf can has more variables like to donate the Al-Quran in the mosque, books in the library and computer for the school. With the consideration that not many people have the tangible assets to contribute, therefore Cash Waqf is introduced. It is for helping Muslims who want to contribute in Waqf, but not have assets to donate. Moreover, it is easier and more affordable to those who have small incomes to still do the practice which can get rewarded for a long time from Allah S.W.T. Thus, everyone can contribute in Cash Waqf if they want to do so. It is because, it does not matter how much money they give, as long as they are intended to give for the sake of Allah S.W.T blessing (Osman et al., 2015).

In view of Islamic perspective, Cash Waqf holds an important role to develop Ummah or society. It is where the practice of Cash Waqf promotes mutual help and assistance among Muslims. This culture encourages the wealthier to always remember the poorer, lead them to contribute their money to Waqf fund. Allah likes people who like to help others, as in surah Al-Baqarah verse 261;

"The likeness of those who spend their wealth in the way of Allah, is as the likeness of a grain (of corn); it grows seven ears, and each ear has a hundred grains. And Allah gives manifold increase to whom He wills. And Allah is All-Sufficient for His creatures' needs, AllKnower." (2:261)

In Cairo, the establishment of University Al-Azhar in 972 is one of the examples of cash waqf whereby the development of the building and the expenses of it are funded by Cash Waqf. This is one of the examples that show us how cash waqf is very important in giving a benefit to the society. This university has produced many successful people around the world. Thus, it means that in terms of education, cash waqf can play a vital role.

During the Ottoman period and at the end of the $16^{\text {th }}$ century, the concept of cash waqf was fully accepted by the entire Antonia and European provinces of the Ottoman Empire which also reigned some parts of South-eastern Europe, the Middle East and North Africa. During that time, the collection of cash waqf was used to purchase and develop many types of fixed assets such as schools, libraries, hospitals, water channels, bridges, roads, ports and lighthouses (Mohsin, 2009).

However, in Malaysia, Afandi \& Nufus, (2010) reported that the collection of cash waqf fund still far from expectation. The latest reported by Yayasan Waqf Malaysia (YWM) that the collection of cash waqf per employed Muslims in Malaysia is just RM0.28 which indicates low amount. In Malaysia, the low cash waqf collection level indirectly indicates the awareness 
about cash waqf is not at a good level. There are also a few factors that might contribute to this situation. This is supported by the research done by Jalil et al., (2017); Allah Pitchay et al., (2018); Ab Fatah et al (2017); Adeyemi et al (2016). Hence, there are many studies investigate on the factors that influence the intention for cash waqf contribution.

Besides that, based on Hasanah \& Pranata (2019); Fauzi et al (2019); Adeyemi et al (2016) proposed that applying technology advancement in cash waqf makes the waqf collection more efficient and effective. Therefore, technology could be one of the factors that migh increase awareness for cash waqf, in the same time will enhance collection of cash waqf with advancement and innovation using technology implementation.

Rapid development of ICT use could be one of the elements that contribute to the economic and social development in Malaysia. It is supported by Kriz \& Qureshi (2009) and Dinc (2016) that ICT is a tool to economic development. In fact, most countries around the world have used various approaches to implement ICT usage in society through community development projects.

In the early 2020, the world faced Covid-19 which caused high number of deaths. Most countries implement lockdown for a few months because of the unusual fast rate of the virus spread, the widest scope of infection, and the difficulty to prevent and control the virus since its spread in China (Kidman \& Chang, 2020; Kraemer et al., 2020; Zhou et al., 2020) The biggest impact to the country is everyone needs to embrace technology as the world needs to implement lockdown and people must perform most affairs from home. This was exemplified by China as most companies in the country could immediately adapt to the new norms due to their technological capabilities (Siva, 2020).

As for Malaysia, the COO of MDEC, Dato' Wan Peng highlighted that the pandemic has changed the country to be a lot more technological and digital friendly, contributing to the rise in fintech activity of late (Fong, 2020). This situation causes the marketplace to adjust to new realities and fintech is already adapting to the changes since the start of the pandemic. It is expected to be the solution to solve the problem for post Covid19 too because the way things are done change after that.

This would be a benchmark for cash waqf as using technology is already worlwide nowadays, hence cash waqf could use this oppurtunity to be implement ic cash waqf.

\section{Hipothesis}

In this reserach, there are two exploratory variables which are technology acceptance (TA) and technology usage (TU). Acceptance of technology or technology acceptance (TA) is important in promoting contribution of cash waqf as highlighted in the research by Amin et al., (2014). It is supported by Tri Kurniawati et al (2021) who conclude that the higher people's acceptance on the technology, the higher their intention to donate and participate in the charity projects. However, it is directly contrast to the study of Zheng (2020) who found negative relationship between perceived ease of use and attitude toward using technology for donation. It shows negative relationship between acceptance of technology and intention to donate. It was supported by Mensah (2019) who found performance expectancy to be insignificant relationship with the technology used services for payment.

The influence of technology acceptance on giving is shown by in the research done by Fauzi, Yahya, Haron, et al (2019) that the greater the easy access of waqf contribution through technology usage will increase the contribution of cash waqf. It was supported by Tri Kurniawati et al., (2021); Kasri \& Yuniar, (2021); Zheng (2020); Li et al (2018) who have positively related between technology usage and intention to donate, and they conclude that 
intention to make donation influence by technology usage. The satisfaction from donating using the technology increases the intention to donate. Furthermore, they can feel satisfaction from making such donation without being worried having to spend a high amount of money (Tri Kurniawati et al., 2021). Kasri \& Yuniar, (2021) highlighted that facilitating condition has become a factor that significantly influences the intention to use online platforms to pay zakat.

Thus, the effects of technology acceptance and technology usage could influence the intention of cash waqf contribution. The effects of technology acceptance and technology usage are as follows:

H1: Technology Acceptance (TA) has a positive relationship on intention to contribute cash waqf (BI). waqf $(\mathrm{BI})$.

H2: Technology Usage (TU) has a positive relationship on intention to contribute cash

\section{Methodology}

This study employs quantitative research methodology. The main objective of this study is to determine the effect of technology acceptance (TA) and technology usage (TU) to the individual's intention of cash waqf contribution. Therefore, the best method to employ is a quantitative method which involves investigation into social or human problems that is based on theoretical model tests. In addition, this study used PLE-SEM method to illustrate the factors that motivate individual contributors to contribute cash waqf based on the data collected using questionnaires.

This study intends to examine factors behind the techology aided contribution of Muslims toward cash waqf. The targeted respondents would be working Muslims in public or private sector or self-employed. The respondents are employed Muslim similar to the study of Pitchay et al. (2015) that investigated factors that influence the behavioral intentions of Muslim employees to contribute to cash waqf through employed Muslims.In this present study, 284 questionnaires were distributed.

\section{Findings}

Data was analysed through PLS-SEM. All the 284 data were used to get the findings. In PLS-SEM, the data go through two asssessment model which are first, measurement model and structural model.

\section{Assessment of Measurement Model}

In evaluating the measurement model, there are several measures that need to be evaluated such like indicator reliability, internal consistency reliability, convergent validity and discriminant validity. The researcher may proceed to structural model after achieved all the benchmark of the requirement in the first measurement model. The evaluation of measurement model used to assess the value of the outer loadings, Composite Reliability $(\mathrm{CR})$, Average Variance Extracted (AVE), and convergent validity (HTMT). While the evaluation of structural model used to assess R square, path coefficient, Variance Inflation Factor (VIF), confidence interval bias correlated and $Q$ square value. 
All indicators have outer loadings of more than 0.708 except for eight indicators, however, only seven indicators namely B6, C2, C3, D4, E5, F1, G4 were removed while the other indicators were retained because it is allowed to remove only $20 \%$ from the total indicators. Thus, indicators with outer loading below than 0.5 were deleted (Hair et al., 2014).

The indicator of the reliability of the item needs the loading to be at least 0.70 for each item in the construct to indicate adequate convergence or internal consistency between the items (Thurasamy et al., 2009). The composite reliability in this study reported in table 1 and the result shows that all constructs under this research have $C R$ value more than the threshold value of 0.7 . Hence, the internal consistency reliability is fulfilled.

Table 1: Value of Composite Reliability

\begin{tabular}{|l|l|}
\hline Constructs & Composite reliability \\
\hline Technology Acceptance-TA & 0.910 \\
\hline Technology Usage-TU & 0.940 \\
\hline
\end{tabular}

AVE with values of more than 0.50 exhibits the ability of the constructs to explain more than half of the variance of its indicators (Hair et al., 2014). The results in this study indicate that the AVE for all the constructs had achieved a value of more than 0.50 which is 0.716 and 0.797 after deleting seven items as mentioned previously, thus it shows that all the items fulfil the requirement for achieving the minimum indicator (Fornell \& Larcker, 1981). The results are presented in Table 2 demonstrates the value of AVE for each item and it were achieved minimum of 0.5 (Hair et. al., 2014).

Table 2: Value of Average Extract Variance (AVE)

\begin{tabular}{|l|l|}
\hline First Order Constructs & $\begin{array}{l}\text { Average Variance Extract } \\
\text { (AVE) }\end{array}$ \\
\hline Technology Acceptance-TA & 0.716 \\
\hline Technology Usage-TU & 0.797 \\
\hline
\end{tabular}

In this research, discriminant validity in the measurement model was tested based on the Heterotrait-monotrait ratio (HTMT) criteria (Hair et al., 2014;2019). In order for the construct to achieve discriminant validity based on the HTMT ration, the value of HTMT obtained must not exceed the threshold value of 0.85 . Referring to the threshold value of 0.85 for HTMT.85, the results indicate that the discriminant validity has been established and meets the threshold range of below 0.85 (Hair et al., 2014).

Table 3: Heterotrait- Monotrait (HTMT) in Assessing Discriminant Validity

\begin{tabular}{|l|l|l|l|l|l|l|}
\hline & ATT & BI & PBC & SN & TA & TU \\
\hline TA & 0.548 & 0.517 & 0.727 & 0.537 & & \\
\hline TU & 0.536 & 0.496 & 0.615 & 0.527 & 0.823 & \\
\hline
\end{tabular}

Overall, the results obtained in all the tests were satisfactory. Specifically, the indicator loadings for the indicator reliability test and internal consistency had achieved a value of more than 0.708 with AVE for convergent validity tests achieving more than 0.50 . For the discriminant validity test, the values obtained in HTMT ratio are satisfactory (at below 0.85 of 
HTMT.85) to establish the discriminant validity in the measurement model. Thus, the researcher could proceed to the next step; structural model.

\section{Assessment of Structural Model}

The validity of the structural model is assessed using the coefficient of determination (R2) and path coefficients.

The results in Table 4 indicate the values of VIF (Variance Inflation Factor) for components of technology acceptance and technology usage as predictors of behaviour intention which are 2.429 and 2.298 which are less than the threshold values of 5 . Therefore, the collinearity between the constructs is not an issue in the structural model (Hair et al., 2014).

Table 4: Result of Collinearity Between Constructs

\begin{tabular}{|l|l|}
\hline & VIF \\
\hline TA & 2.429 \\
\hline TU & 2.298 \\
\hline
\end{tabular}

The $R 2$ value indicates the amount of variance in dependent variables that is explained by the independent variables. Thus, a larger R2 value increases the predictive ability of the structural model. It shows in Table 5 below.

Table 5: Assessment of $R^{2}$ value

\begin{tabular}{|c|c|}
\hline Endogenous Constructs & $\mathrm{R}^{2}$ \\
\hline Behavioural Intention & 0.334 \\
\hline
\end{tabular}

According to scholarly research focusing on marketing issues, $R 2$ values of $0.75,0.50$, or 0.25 for endogenous latent variables can be defined as major, moderate, or poor, respectively (Hair et al., 2014). Thus, the $\mathrm{R} 2$ values of $33.4 \%$ obtained for firm output as an endogenous construct are moderate.

Each path connecting two latent variables in the structural model represented a hypothesis. The structural model analysis helps the researcher to confirm or disconfirm each hypothesis as well as determine the strength of the relationship between dependent and independent variables.

The SmartPLS bootstrapping feature is used to produce t-statistics for all directions in order to measure the significant level. The significance level of each relationship is calculated using the t-statistics output. For each hypothesised path, Table 6 lists the path coefficients, observed t-statistics, and significance level. The acceptance or rejection of the suggested hypotheses is decided using the route evaluation findings. 
Table 6: Path Coefficients, Observed T-Statistics, and Significance Level for all Hypothesis Tested

\begin{tabular}{|l|l|l|l|l|l|}
\hline & $\begin{array}{l}\text { Original } \\
\text { Sample (O) } \\
\text { Path } \\
\text { Coefficient/ } \beta\end{array}$ & $\begin{array}{l}\text { Standard } \\
\text { Deviation } \\
\text { (STDEV) }\end{array}$ & $\begin{array}{l}\text { T-Statistics } \\
(\mid \text { O/STDEV|) }\end{array}$ & $\begin{array}{l}\text { Significant } \\
\text { level/ } \\
\text { P Values }\end{array}$ & Result \\
\hline TA -> BI & 0.132 & 0.08 & 1.654 & 0.099 & $\begin{array}{l}\text { Not } \\
\text { Significant }\end{array}$ \\
\hline TU -> BI & 0.144 & 0.069 & 2.1 & 0.036 & Significant \\
\hline
\end{tabular}

In this measurement, if the Q2 is greater than 0 , the structural model is considered to be predictive relevance. Table 7 shows the result of Q2 obtained from the blindfolding procedure as 0.298 .

Table 7: Assessment of Predictive Relevance Q

\begin{tabular}{|l|l|l|l|}
\hline & SSO & SSE & $\begin{array}{l}\mathrm{Q}^{2} \quad(=1- \\
\text { SSE/SSO) }\end{array}$ \\
\hline $\mathrm{BI}$ & 1136 & 797.034 & 0.298 \\
\hline
\end{tabular}

\section{Conclusion}

Based on the findings of this study, technology acceptance is not significant. On the other hand, technology usage is significant to the research. It can be concluded that technolgy acceptance is seem like to be not relevant to the factors of intention to contribute cash waqf. It is because, acceptance on technology is not guaranteed to influence Muslims to contribute cash waqf. However, technology usage is much important with its characteristics of accessibility, convenience and user friendly would be able to convince muslims to pay their cash waqf contributions. In other words, acceptance of technology by individuals could be developed if the method of technology used is good and excellent from the perspective of end users. Thus, this study could be used by the relevant waqf organizations to enhance their technology applications to convince more muslims to contribute cash waqf.

This paper recommend to implement technology advancement in expectation to increase contribution of cash waqf. This could be more easy to ensure its succesfull since nowadays, technology is something that is very important and improved from time to time. Cash waqf is one of the way for Muslims to practice philanthropy in their life. With the convenience and flexibility of cash waqf collection, it would encourage more Muslims to contribute. Technology usage need to be a stepping stone for cash waqf to be more attractive and well known in future.

\section{References}

Mohsin, A. M., \& Muneeza, A. (2019). Integrating Waqf Crowdfunding into the Blockchain. In U. A. Oseni \& S. N. Ali (Eds.), Fintech in Islamic Finance Theory and Practice (pp. 266280).

Ab Fatah, N. S., Mansor, N., Ripain, N., \& Endut, W. A. (2017). Waqf Participation and Awareness; An Exploratory Study in the West Coast of Sabah, Malaysia. International Journal of Research Science \& Management, 4(6).

https://doi.org/10.18514/MMN.2020.2947

Mohsin, A. M. I. (2009). Cash Waqf: A New Financial Product. Prentice Hall. 
Mohsin, A. M. I., Dafterdar, H., Cizakca, M., Alhabshi, S. O., Sadr, S. K., Anwar, T., \& Obaidullah, M. (2016). Palgrave Studies in Islamic Banking, Finance, and Economics (Z. Iqbal, J. Sultan, \& M. Asutay (Eds.)). Palgrave Macmillan.

Adeyemi, A. A., Ismail, N. A., \& Hassan, S. S. B. (2016). An empirical investigation of the determinants of cash Waqf awareness in Malaysia. Intellectual Discourse, 24, 501520.

Afandi, A., \& Nufus, D. N. (2010). Analysis on Cash Waqf Return Fund Allocation in Indonesia : A Case Study in Indonesian Waqf Deposit. Tauhid Epistemology In Increasing The Number Of Zakat-Of-Wealth Payers And Its Contribution Toward The Development Of Malaysia Economy, 54-63.

Pitchay, A., Thaker, M. T. M. A., Mydin, A. A., Azhar, Z., \& Abdul Latiff, A. R. (2018). Cooperative-waqf model: a proposal to develop idle waqf lands in Malaysia. ISRA International Journal of Islamic Finance, 10(2), 225-236. https://doi.org/10.1108/IJIF07-2017-0012

Amin, H., Abdul-Rahman, A. R., Ramayah, T., Supinah, R., \& Mohd-Aris, M. (2014). Determinants of online waqf acceptance: An empirical investigation. Electronic Journal of Information Systems in Developing Countries, 60(1), 1-18. https://doi.org/10.1002/j.1681-4835.2014.tb00429.x

Dinc, M. (2016). Introduction to Regional Economic Development. In Introduction to Regional Economic Development (Issue December 2015). https://doi.org/10.4337/9781785361357

Fauzi, M. H., Yahya, S., Hanaysha, J. R., Haron, M. S., \& Abu Zahrin, S. N. (2019). The Impact of Trust in Cash Waqf Contribution: A Case Study of Wakaf Selangor Muamalat (WSM) Service Of Bank Muamalat Malaysia Berhad (BMMB). International Journal of Business, Economics and Law, 18(2), 1-10.

Fong, V. (2020). Experts Share Their Views on How Fintechs Can Navigate the COVID-19 Crisis. FinTech Malaysia FinTech News. https://fintechnews.my/23164/various/expertsshare-their-views-on-how-the-fintechs-can-navigate-the-covid-19-crisis/

Fornell C \& Larcker F David. (1981). Evaluating Structural Equation Models with unobservale variables and measurement error. Journal of Marketing Research, 18(1), 39-50

Hair, J., Sarstedt, M., Hopkins, L., \& Kuppelwieser, V. G. (2014). Partial least squares structural equation modeling ( PLS-SEM ) An emerging tool in business research. European Business Review, 26(2), 106-121. https://doi.org/10.1108/EBR-10-2013-0128

Hair, Joseph F., Risher, J. J., Sarstedt, M., \& Ringle, C. M. (2019). When to use and how to report the results of PLS-SEM. European Business Review, 31(1), 2-24. https://doi.org/10.1108/EBR-11-2018-0203

Hasanah, U., \& Pranata, D. (2019). Waqf Financial Tecnology in Startup Capital. International Conference on IslamicDevelopment Studies. https://doi.org/10.4108/eai.10-92019.2289331

Jalil, M. I. A., Pitchay, A. A., \& Yahya, S. (2017). Cash Waqf and Preferred Method of Payment: Case of Malaysia Using an AHP Approach. Revitalization of Waqf for Socio-Economic Development, 2(January 2019), 187-206. https://doi.org/10.1007/978-3-030-184490_10

Johari, F. (2020). Personal Communication January 2nd, 2020.

Kasri, R. A., \& Yuniar, A. M. (2021). Determinants of digital zakat payments : lessons from Indonesian experience. https://doi.org/10.1108/JIABR-08-2020-0258 
Kidman, G., \& Chang, C. H. (2020). What does "crisis" education look like? International Research in Geographical and Environmental Education, 29(2), 107-111. https://doi.org/10.1080/10382046.2020.1730095

Kraemer, M. U. ., Yang, C.-H., Gutierrez, B., Wu, C.-H., \& Klein, B. (2020). The Effect of Human Mobility and Control Measure on the COVID-19 Epidemic in China. Science, 4218(March).

Kriz, K., \& Qureshi, S. U. E. (2009). The Role of Policy in the Relationship between ICT Adoption and Economic Development: A Comparative Analysis of Singapore and Malaysia. GlobDev 2009, 1-31. http://aisel.aisnet.org/globdev2009/13

Li, Y. Z., He, T. L., Song, Y. R., Yang, Z., \& Zhou, R. T. (2018). Factors impacting donors' intention to donate to charitable crowd-funding projects in China: a UTAUT-based model. Information Communication and Society, 21(3), 404-415. https://doi.org/10.1080/1369118X.2017.1282530

Mat Doa, M. B. (2020). Yayasan Wakaf Malaysia.

Mensah, I. K. (2019). Factors Influencing the Intention of University Students to Adopt and Use E-Government Services: An Empirical Evidence in China. SAGE Open, 9(2). https://doi.org/10.1177/2158244019855823

Nasiri, A., Noori, A., \& Salleh, M. C. M. (2019). Acceptance and Practices of Cash WAQF among University's Students. International Journal of Academic Research in Accounting, Finance and Management Sciences, 9(3), 38-48. https://doi.org/10.6007/ijarafms/v9i3/6325

Osman, A. F., Mohammed, M. O., \& Fadzil, A. (2015). Factor Influencing Cash Waqf Giving Behavior: A Revised Theory of Planned Behavior. Journal of Global Business and Social Entrepreneurship, 33-48.

Pitchay, A. A., Meera, A. K. M., \& Saleem, M. Y. (2015). Factors influencing the behavioral intentions of muslim employees to contribute to cash-waqf through salary deductions. Journal of King Abdulaziz University, Islamic Economics, 28(1), 63-100. https://doi.org/10.4197/Islec.28-1.3

Puad, N. A. M., Rafdi, N., \& Shah, S. W. S. (2014). Issues and Challenges of Waqf Instrument: A Case Study in MAIS. E-Proceedings of the Conference on Management and Muamalah, May 2014, 116-127. https://doi.org/10.1007/s13398-014-0173-7.2

Sabit, M. T. (2008). Sustaining The Means of Sustainability : The Need For Accepting Wakaf ( Waqf ) Assets In Malaysian Property Market. The 14th Annual Conference of the Pacific Rim Real Estate Society, 1-17.

Sargeant, A., \& Woodliffe, L. (2005). The antecedents of donor commitment to voluntary organizations. Nonprofit Management and Leadership, 16(1), 61-78. https://doi.org/10.1002/nml.90

Siva, R. (2020). Covid-19: ClO Of The Year? Insights Within Malaysia Digital Economy. https://mdec.my/blog/?p=626

Thaker, M., T. (2018). Factors Influencing the Adoption of the Crowdfunding- Waqf Model (CWM) in the Waqf Land Development. Journal of Islamic Marketing, 9(3), 1-39.

Thurasamy, R., Mohamad, O., Omar, A., \& Marimuthu, M. (2009). Technology Adoption among Small and Medium Enterprises (SME's): A Research Agenda. International Journal of Social, Behavioral, Educational, Economic, Business and Industrial Engineering, 3(May), 512-515. 
Kurniawati, T. D., Rosita, N. H., \& Anggraeni, R. (2021). The role of emotional marketing and UTAUT on donation intention through social media. International Journal of Research in Business and Social Science (2147-4478), 10(1), 38-46. https://doi.org/10.20525/ijrbs.v10i1.1026

Zheng, Y. (2020). Using Mobile Donation to Promote International Fundraising: A Situational Technology Acceptance Model. International Journal of Strategic Communication, 14(2), 73-88. https://doi.org/10.1080/1553118X.2020.1720026

Zhou, L., Wu, S., Zhou, M., \& Li, F. (2020). 'School's Out, But Class' On', The Largest Online Education in the World Today: Taking China's Practical Exploration During The COVID19 Epidemic Prevention and Control As an Example. SSRN Electronic Journal, 4(2), 501-509. https://doi.org/10.2139/ssrn.3555520 